\title{
Influence of Quaternization on UCST Properties of Hydroxyl-Derivatized Polymers
}

\author{
Hyung-il Lee \\ Department of Chemistry, University of Ulsan, Ulsan 680-749, Korea. E-mail: sims0904@ulsan.ac.kr \\ Received April 30, 2014, Accepted June 17, 2014
}

\begin{abstract}
A series of hydroxyl-derivatized quaternized polymers were successfully synthesized by atom transfer radical polymerization (ATRP) and $\mathrm{Cu}(\mathrm{I})$-catalyzed 1,3-dipolar cycloaddition of azide and alkynes (click chemistry), followed by quaternization reactions. ATRP was employed to synthesize poly(2-hydroxyethyl methacrylate) (PHEMA), followed by introduction of alkyne groups using pentynoic acid, leading to HEMA-Alkyne. 2Azido-1-ethanol and 3-azido-1-propanol were combined with the HEMA-Alkyne backbone via click reaction, resulting in triazole-ring containing hydroxyl-derivatized polymers. Quaternization reactions with methyl iodide were conducted on the triazole ring of each polymer. Molecular weight, molecular weight distribution, and the degree of quaternization (DQ) were determined by gel permeation chromatography (GPC) and ${ }^{1} \mathrm{H}$ NMR spectroscopy. The average molecular weight $\left(\mathrm{M}_{\mathrm{n}}\right)$ of the resulting polymers ranged from $5.9 \times 10^{4}$ to 1.05 $\times 10^{5} \mathrm{~g} / \mathrm{mol}$ depending on the molecular architecture. The molecular weight distribution was low $\left(\mathrm{M}_{\mathrm{w}} / \mathrm{M}_{\mathrm{n}}=\right.$ 1.26-1.38). The transmission spectra of the $0.1 \mathrm{wt} \%$ aqueous solutions of the resulting quaternized polymers at $650 \mathrm{~nm}$ were measured as a function of temperature. Results showed that the upper critical solution temperature (UCST) could be finely controlled by the level of DQ.
\end{abstract}

Key Words : ATRP, Quaternized, Click reactions, UCST, Thermoresponsive

\section{Introduction}

Stimuli-responsive polymers undergo dramatic changes of their physical and chemical properties in response to small external changes in the environmental condition, including $\mathrm{pH}$, temperature, and light, etc. ${ }^{1-6}$ Especially, thermoresponsive polymers exhibit thermally induced, reversible phase transitions that are caused by a sudden change in the solvation state. ${ }^{7}$ Depending on whether reversible phase transition is found at low or high temperatures, an upper or lower critical solution temperature (UCST ${ }^{8-10}$ or LCST) exists, respectively. LCST systems are usually restricted to an aqueous solvent environment, which are primarily of interest for biomedical applications. UCST systems, however, have been also studied in organic solvents. ${ }^{11-13}$

UCST behavior can happen when interpolymer interactions are gradually weakened upon heating. For example, zwitterionic polybetaines have strong electrostatic (ionic) interactions between polymer chains. These interaction can be readily disrupted upon heating, which renders polymer to be soluble in water. The UCST of polymers is also driven by the presence of ionic impurites or hydrogen bonding ${ }^{14}$ between hydrogen bond donors and acceptors such as poly(allylurea), ${ }^{15}$ poly(6-(acryloyloxymethyl)uracil), ${ }^{16}$ and poly$\left(\mathrm{N}\right.$-acryloylasparaginamide (NAAAM)). ${ }^{17}$

Previously, we reported the synthesis and UCST behavior of a series of ureido-derivatized polymers with different degrees of quaternization (DQ) of their triazole rings. ${ }^{18}$ As a continuous effort to develop polymeric UCST systemes in water, we synthesized thermoresponsive hydroxyl-derivatized quaternized polymers. This work represents the first example of UCST tuning of hydroxyl-derivatized polymers simply by DQ.

\section{Experimental}

Materials. 2-Hydroxyethyl methacrylate (HEMA, 95\%, Tokyo Chemical Industry; TCI) passed through basic alumina column to remove the monomethyl ether hydroquinone inhibitor. 2,2'-Bipyridyl (bpy), ethyl $\alpha$-bromoisobutyrate (EBiB), $\mathrm{CuCl}(99 \%), \mathrm{CuCl}_{2}$ (99\%), $\mathrm{CuBr}$ (98\%), 4-dimethylaminopyridine (DMAP), $N, N^{\prime}$-dicyclohexylcarbondimide (DCC), 4-pentynoic acid, diethyl ether, $N, N, N^{\prime}, N^{\prime \prime}, N^{\prime \prime}$-pentamethyldiethylenetriamine (PMDETA), 2-bromoethanol, 3-chloro1-propanol, and methyl iodide were purchased from Aldrich with the highest purity and were used as received without further purification. Sodium azide $\left(\mathrm{NaN}_{3}\right)$, anisole, methanol, and methylene chloride (MC) were purchased from TCI and used as received.

Instrumentation. ${ }^{1} \mathrm{H}$ NMR spectra were recorded in DMSO- $d_{6}$ and $\mathrm{CDCl}_{3}$ on a Bruker avance $300 \mathrm{MHz}$ NMR spectrometer. The apparent molecular weights and molecular weight distributions were measured by gel permeation chromatography (GPC) (Agilent Technologies 1200 series) using a polystyrene (PS) standard, with DMF as the eluent at $30{ }^{\circ} \mathrm{C}$ and a flow rate of $1.00 \mathrm{~mL} / \mathrm{min}$. The cloud points of the polymer solutions in water were measured on a Thermo Scientific Evolution 600 UV-Vis spectrophotometer equipped with a digital temperature controller. A $650 \mathrm{~nm}$ wavelength was used to determine UCST. Sample cells $(1 \mathrm{~cm})$ were thermostated with a water jacket ranged from 15 to 95 ${ }^{\circ} \mathrm{C}$ with a cooling ingrate of $1{ }^{\circ} \mathrm{C} / \mathrm{min}$. The cloud point was defined as the middle point of the transmittance change.

2-Azido-1-ethanol (1): $\mathrm{NaN}_{3}(16.8 \mathrm{~g}, 0.258 \mathrm{~mol})$ was 
added to a solution of 2-bromoethanol (10 g, $0.086 \mathrm{~mol})$ in water $(100 \mathrm{~mL})$. The reaction mixture was heated to $60{ }^{\circ} \mathrm{C}$ for $15 \mathrm{~h}$, extracted with diethyl ether, dried over $\mathrm{MgSO}_{4}$, and concentrated to give volatile colorless oil. ${ }^{1} \mathrm{H}$ NMR $(300$ $\left.\mathrm{MHz}, \mathrm{CDCl}_{3}\right) \delta 3.72\left(2 \mathrm{H}, \mathrm{t}, \mathrm{CH}_{2} \mathrm{CH}_{2} \mathrm{OH}\right) ; 3.39(2 \mathrm{H}, \mathrm{t}$, $\left.\mathrm{N}_{3} \mathrm{CH}_{2} \mathrm{CH}_{2}\right) ; 2.80\left(1 \mathrm{H}, \mathrm{s}, \mathrm{CH}_{2} \mathrm{OH}\right)$.

3-Azido-1-propanol (2): ${ }^{1} \mathrm{H}$ NMR $\left(300 \mathrm{MHz}, \mathrm{CDCl}_{3}\right) \delta$ $3.68\left(2 \mathrm{H}, \mathrm{t}, \mathrm{CH}_{2} \mathrm{CH}_{2} \mathrm{CH}_{2} \mathrm{OH}\right) ; 3.39\left(2 \mathrm{H}, \mathrm{t}, \mathrm{N}_{3} \mathrm{CH}_{2} \mathrm{CH}_{2}\right)$; $2.730\left(1 \mathrm{H}, \mathrm{s}, \mathrm{CH}_{2} \mathrm{OH}\right) ; 1.78\left(2 \mathrm{H}, \mathrm{m}, \mathrm{CH}_{2} \mathrm{CH}_{2} \mathrm{CH}_{2}\right)$.

PHEMA. PHEMA was synthesized as described previously. ${ }^{19} \mathrm{M}_{\mathrm{n}}=59,300 \mathrm{~g} / \mathrm{mol}, \mathrm{M}_{\mathrm{w}} / \mathrm{M}_{\mathrm{n}}=1.34 .{ }^{1} \mathrm{H}$ NMR (300 $\left.\mathrm{MHz}, \mathrm{DMSO}-d_{6}\right) \delta 5.0\left(1 \mathrm{H}, \mathrm{s}, \mathrm{CH}_{2} \mathrm{OH}\right) ; 4.1\left(2 \mathrm{H}, \mathrm{s}, \mathrm{O}-\mathrm{CH}_{2-}\right.$ $\left.\mathrm{CH}_{2}\right)$; 3.7 (2H, s, O-CH $\left.-\mathrm{CH}_{2}\right)$; 2.0-1.9 (2H, d, $\mathrm{CH}_{2}-\mathrm{C}\left(\mathrm{CH}_{3}\right)$ ); 1.1-0.94 (3H, d, $\left.\mathrm{CH}_{2}-\mathrm{C}\left(\mathrm{CH}_{3}\right)\right)$.

PHEMA-Alkyne. PHEMA-Alkyne was synthesized as described previously. ${ }^{19} \mathrm{M}_{\mathrm{n}}=69,500 \mathrm{~g} / \mathrm{mol}, \mathrm{M}_{\mathrm{w}} / \mathrm{M}_{\mathrm{n}}=1.26$. ${ }^{1} \mathrm{H}$ NMR (300 MHz, DMSO- $\left.d_{6}\right) \delta$ 4.4-4.27 (4H, d, -O-CH${ }_{2-}$ $\left.\mathrm{CH}_{2}-\mathrm{O}-\right)$; 2.69-2.68 (2H, d, O- $\left.(\mathrm{C}=\mathrm{O})-\mathrm{CH}_{2}-\mathrm{CH}_{2-}\right)$; 2.58-2.56 $\left(2 \mathrm{H}, \mathrm{s}, \mathrm{d}, \mathrm{O}-(\mathrm{C}=\mathrm{O})-\mathrm{CH}_{2}-\mathrm{CH}_{2}-\mathrm{C}-\right)$; 2.18-1.74 (3H, d, $\mathrm{CH}_{2}-$ $\left.\mathrm{C}\left(\mathrm{CH}_{3}\right), \mathrm{CH}_{2}-\mathrm{C}-\mathrm{CH}\right) ; 1.2-0.8\left(3 \mathrm{H}, \mathrm{d}, \mathrm{CH}_{2}-\mathrm{C}\left(\mathrm{CH}_{3}\right)\right)$.

PEA (PHEMA-Alkyne-click-1). The ratio of reagent $[\text { PHEMA-Alkyne }]_{0} /[2 \text {-Azido-1-ethanol }]_{0} /[\mathrm{CuBr}]_{0} /[\mathrm{PMDETA}]_{0}$ was $1 / 2 / 0.1 / 0.1$. The click reaction between PHEMAAlkyne (0.5 g, $2.38 \mathrm{mmol})$ and 2-azido-1-ethanol (0.410 g, $4.76 \mathrm{mmol}$ ) was conducted in $5 \mathrm{~mL}$ of DMF using $\mathrm{CuBr} /$ PMDETA as a catalyst. After $10 \mathrm{~h}$, the polymer solution was exposed to air, diluted with DMF, and passed through neutral alumina to remove the copper catalyst. The resulting polymer was precipitated in diethyl ether and dried in a vacuum oven for $24 \mathrm{~h} . \mathrm{M}_{\mathrm{n}}=97,700 \mathrm{~g} / \mathrm{mol}, \mathrm{M}_{\mathrm{w}} / \mathrm{M}_{\mathrm{n}}=1.31$. ${ }^{1} \mathrm{H}$ NMR (300 MHz, DMSO- $d_{6}$ ) $\delta 7.77(1 \mathrm{H}, \mathrm{s}$, triazole); 4.99 $\left(1 \mathrm{H}, \mathrm{t}, \mathrm{CH}_{2} \mathrm{CH}_{2} \mathrm{OH}\right) ; 4.31\left(2 \mathrm{H}\right.$, t, triazol- $\left.\mathrm{CH}_{2}-\mathrm{CH}_{2}-\mathrm{OH}\right)$; 4.16-4.07 (4H, d, -O-CH $\left.2-\mathrm{CH}_{2}-\mathrm{O}-\right)$; $3.74\left(2 \mathrm{H}\right.$, t, triazol- $\mathrm{CH}_{2}-$ $\left.\mathrm{CH}_{2}-\mathrm{OH}\right) ; 2.88\left(2 \mathrm{H}, \mathrm{s}, \mathrm{d}, \mathrm{O}-(\mathrm{C}=\mathrm{O})-\mathrm{CH}_{2}-\mathrm{CH}_{2}-\mathrm{C}-\right) ; 2.65(2 \mathrm{H}$, $\left.\mathrm{s}, \mathrm{d}, \mathrm{O}-(\mathrm{C}=\mathrm{O})-\mathrm{CH}_{2}-\mathrm{CH}_{2}-\mathrm{C}-\right) ; 2.05-1.3\left(3 \mathrm{H}, \mathrm{d}, \mathrm{CH}_{2}-\mathrm{C}\left(\mathrm{CH}_{3}\right)\right.$, $\left.\mathrm{CH}_{2}-\mathrm{C}-\mathrm{CH}\right) ; 0.92-0.77$ (3H, d, $\left.\mathrm{CH}_{2}-\mathrm{C}\left(\mathrm{CH}_{3}\right)\right)$.

PPA (PHEMA-Alkyne-click-2). $\mathrm{M}_{\mathrm{n}}=105,000 \mathrm{~g} / \mathrm{mol}$, $\mathrm{M}_{\mathrm{w}} / \mathrm{M}_{\mathrm{n}}=1.38 .{ }^{1} \mathrm{H} \mathrm{NMR}\left(300 \mathrm{MHz}, \mathrm{DMSO}-d_{6}\right) \delta 7.77(1 \mathrm{H}$, $\mathrm{s}$, triazole); $4.60\left(1 \mathrm{H}, \mathrm{t}\right.$, triazol- $\left.\mathrm{CH}_{2}-\mathrm{CH}_{2}-\mathrm{CH}_{2}-\mathrm{OH}\right) ; 4.32$ $\left(2 \mathrm{H}, \mathrm{t}\right.$, triazol- $\left.\mathrm{CH}_{2}-\mathrm{CH}_{2}-\mathrm{CH}_{2}-\mathrm{OH}\right)$; 4.07-4.02 (4H, d, -O$\left.\mathrm{CH}_{2}-\mathrm{CH}_{2}-\mathrm{O}-\right) ; 3.43$ (2H, t, triazol- $\left.\mathrm{CH}_{2}-\mathrm{CH}_{2}-\mathrm{CH}_{2}-\mathrm{OH}\right) ; 2.85$ $\left(2 \mathrm{H}, \mathrm{s}, \mathrm{d}, \mathrm{O}-(\mathrm{C}=\mathrm{O})-\mathrm{CH}_{2}-\mathrm{CH}_{2}-\mathrm{C}-\right) ; 2.64(2 \mathrm{H}, \mathrm{s}, \mathrm{d}, \mathrm{O}-(\mathrm{C}=\mathrm{O})-$ $\left.\mathrm{CH}_{2}-\mathrm{CH}_{2}-\mathrm{C}-\right)$; 2.05-1.3 (3H, d, $\left.\mathrm{CH}_{2}-\mathrm{C}\left(\mathrm{CH}_{3}\right) \mathrm{CH}_{2}-\mathrm{C}-\mathrm{CH}\right)$; $3.43\left(2 \mathrm{H}, \mathrm{m}\right.$, triazol- $\left.\mathrm{CH}_{2}-\mathrm{CH}_{2}-\mathrm{CH}_{2}-\mathrm{OH}\right) ; 0.92-0.77(3 \mathrm{H}, \mathrm{d}$, $\left.\mathrm{CH}_{2}-\mathrm{C}\left(\mathrm{CH}_{3}\right)\right)$.

Quaternization of PEA (PEA-MI). A typical procedure for quaternization of PEA with methyl iodide (1:1.5 molar ratio) was as follows. A solution of PEA (0.0377 g, 0.2 mmol of triazole groups) and methyl iodide $(0.043 \mathrm{~g} ; 0.3$ mmol) in DMF $(0.5 \mathrm{~mL})$ was stirred for $16 \mathrm{~h}$ at $45^{\circ} \mathrm{C}$. Quaternized PEA was precipitated in DMF, filtered, and dried under vacuum. Reactions with three different molar ratios $(1: 1.5,1: 2.0,1: 2.5)$ of PEA to methyl iodide were carried out, and the degree of quaternization (DQ) was $4 \%$, $7 \%$, and $10 \%$, respectively. ${ }^{1} \mathrm{H}$ NMR (300 MHz, DMSO- $\left.d_{6}\right)$ $\delta 8.75(1 \mathrm{H}, \mathrm{s}$, quaternized triazole $) ; 7.77(1 \mathrm{H}, \mathrm{s}$, triazole); $4.99\left(1 \mathrm{H}, \mathrm{t}, \mathrm{CH}_{2} \mathrm{CH}_{2} \mathrm{OH}\right) ; 4.61\left(3 \mathrm{H}\right.$, s, triazole- $\left.\mathrm{CH}_{3}\right) ; 4.31$ $\left(2 \mathrm{H}, \mathrm{t}\right.$, triazole- $\left.\mathrm{CH}_{2}-\mathrm{CH}_{2}-\mathrm{OH}\right) ; 4.17-4.07$ (4H, d, -O-CH${ }_{2}^{-}$ $\left.\mathrm{CH}_{2}-\mathrm{O}-\right) ; 3.74$ (2H, t, triazol- $\left.\mathrm{CH}_{2}-\mathrm{CH}_{2}-\mathrm{OH}\right) ; 2.88(2 \mathrm{H}, \mathrm{s}, \mathrm{d}$, $\left.\mathrm{O}-(\mathrm{C}=\mathrm{O})-\mathrm{CH}_{2}-\mathrm{CH}_{2}-\mathrm{C}-\right)$; $2.65\left(2 \mathrm{H}, \mathrm{s}, \mathrm{d}, \mathrm{O}-(\mathrm{C}=\mathrm{O})-\mathrm{CH}_{2}-\mathrm{CH}_{2}-\right.$ C-): 2.05-1.3 (3H, d, $\left.\mathrm{CH}_{2}-\mathrm{C}\left(\mathrm{CH}_{3}\right), \mathrm{CH}_{2}-\mathrm{C}-\mathrm{CH}\right) ; 0.92-0.77$ $\left(3 \mathrm{H}, \mathrm{d}, \mathrm{CH}_{2}-\mathrm{C}\left(\mathrm{CH}_{3}\right)\right)$.

Quaternization of PPA (PPA-MI). Reactions with three different molar ratios $(1: 1.5,1: 2.0,1: 2.5)$ of PPA to methyl iodide were carried out, and the degree of quaternization (DQ) was $3 \%, 8 \%$, and $11 \%$, respectively. ${ }^{1} \mathrm{H}$ NMR (300 $\left.\mathrm{MHz}, \mathrm{DMSO}-d_{6}\right) \delta 8.75(1 \mathrm{H}$, s, triazole); $7.77(1 \mathrm{H}, \mathrm{s}$, triazole); $4.60\left(1 \mathrm{H}\right.$, t, triazol- $\left.\mathrm{CH}_{2}-\mathrm{CH}_{2}-\mathrm{CH}_{2}-\mathrm{OH},\right) ; 4.32(2 \mathrm{H}$, t, triazole$\left.\mathrm{CH}_{2}-\mathrm{CH}_{2}-\mathrm{CH}_{2}-\mathrm{OH}\right) ; 4.07-4.02$ (4H, d, -O-CH2-CH2-O-); $3.43\left(2 \mathrm{H}, \mathrm{t}\right.$, triazol- $\left.\mathrm{CH}_{2}-\mathrm{CH}_{2}-\mathrm{CH}_{2}-\mathrm{OH}\right) ; 2.85(2 \mathrm{H}, \mathrm{s}, \mathrm{d}, \mathrm{O}-$ $\left.(\mathrm{C}=\mathrm{O})-\mathrm{CH}_{2}-\mathrm{CH}_{2}-\mathrm{C}-\right)$; $2.64\left(2 \mathrm{H}, \mathrm{s}, \mathrm{d}, \mathrm{O}-(\mathrm{C}=\mathrm{O})-\mathrm{CH}_{2}-\mathrm{CH}_{2}-\mathrm{C}-\right)$; 2.05-1.3 (3H, d, $\left.\mathrm{CH}_{2}-\mathrm{C}\left(\mathrm{CH}_{3}\right) \mathrm{CH}_{2}-\mathrm{C}-\mathrm{CH}\right) ; 3.43(2 \mathrm{H}, \mathrm{m}$, triazol-CH2-CH2-CH2-OH); 0.92-0.77 (3H, d, $\left.\mathrm{CH}_{2}-\mathrm{C}\left(\mathrm{CH}_{3}\right)\right)$.

\section{Results and Discussion}

The strategy employed in this study is schematically illustrated in Scheme 1. PHEMA with a controlled molecular weight and low polydispersity was synthesized via atom transfer radical polymerization (ATRP) $)^{20,21}$ from EBiB initiator using $\mathrm{CuCl} / \mathrm{bpy}$ as the catalyst. The molecular weight and molecular weight distribution of the resulting PHEMA were obtained using a GPC DMF line with PS standards $\left(M_{n}\right.$ $=59300 \mathrm{~g} / \mathrm{mol}, \mathrm{M}_{\mathrm{w}} / \mathrm{M}_{\mathrm{n}}=1.34$ ) (Figure 1 and Table 1). The

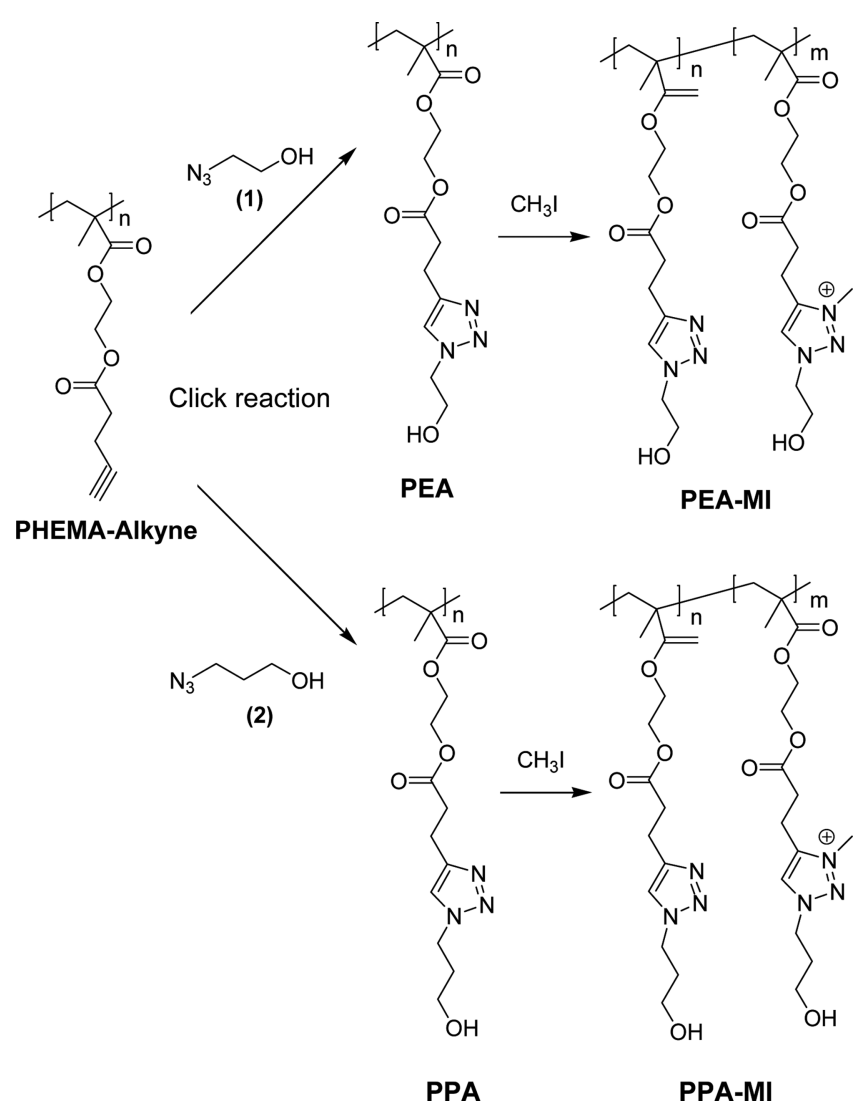

Scheme 1. Synthesis of hydroxyl-derivatized quaternized polymers by combination of ATRP and click chemistry, followed by quaternization with methyl iodide. 


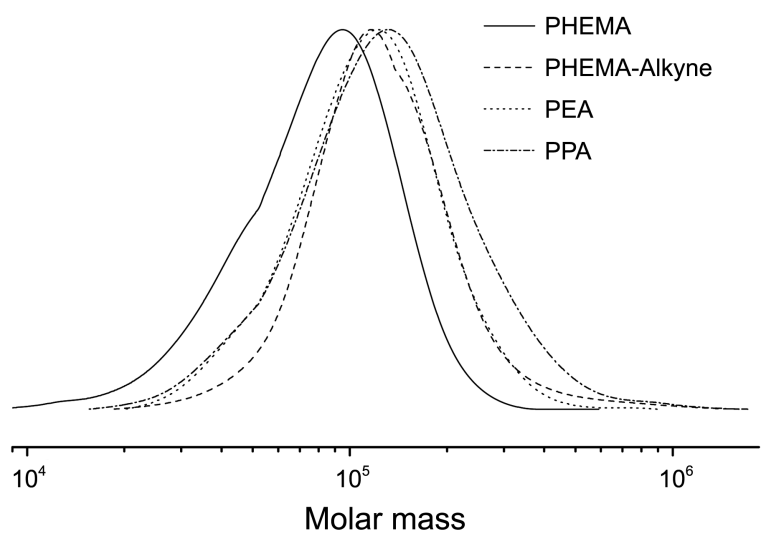

Figure 1. DMF GPC traces of PHEMA, PHEMA-Alkyne, PEA, and PPA.

Table 1. Summary of DMF GPC results

\begin{tabular}{cccc}
\hline & $\begin{array}{c}M_{\mathrm{n}} \text { theory }^{a} \\
(\mathrm{~g} / \mathrm{mol})\end{array}$ & $\begin{array}{c}M_{\mathrm{n}}{ }^{b}{ }^{b} \\
(\mathrm{~g} / \mathrm{mol})\end{array}$ & PDI $^{b}$ \\
\hline PHEMA & $26000^{a}$ & 59300 & 1.34 \\
PHEMA-alkyne & 31500 & 69500 & 1.26 \\
PEA & 39900 & 97700 & 1.31 \\
PPA & 38600 & 105000 & 1.38 \\
\hline
\end{tabular}

${ }^{a}$ Theoretical molecular weight determined from monomer conversions. ${ }^{b}$ Apparent number-average molecular weight and polydispersity index (PDI) determined by DMF GPC with PS calibration.

apparent molecular weight obtained by GPC was higher than the theoretical molecular weight $\left(\mathrm{M}_{\mathrm{n}}\right.$, theory $\left.=26000 \mathrm{~g} / \mathrm{mol}\right)$ calculated from the HEMA conversion $\left(\mathrm{M}_{\mathrm{n}}\right.$, theory $=$ conversion $\left.\times \mathrm{MW}_{\mathrm{HEMA}} \times[\mathrm{HEMA}]_{0} /[\mathrm{EBiB}]_{0}\right)$ due to the differences in hydrodynamic volumes of PHEMA and PS standards. In the next step, DCC coupling of PHEMA with 4-pentynoic acid yielded PHEMA-Alkyne $\left(\mathrm{M}_{\mathrm{n}}=69500 \mathrm{~g} / \mathrm{mol}, \mathrm{M}_{\mathrm{w}} / \mathrm{M}_{\mathrm{n}}=\right.$ 1.26) as the polymer backbone. The successful synthesis of PHEMA-Alkyne was confirmed by ${ }^{1} \mathrm{H}$ NMR spectra. It was monitored that peak (e) of PHEMA at $4.85 \mathrm{ppm}$ disappeared while peak (g) of PHEMA-Alkyne appeared at $2.7 \mathrm{ppm}$ (Figure 2). The GPC traces in Figure 1 show that the apparent molecular weight of PHEMA-Alkyne backbone increased slightly after transformation.

2-Azido-1-ethanol (1) and 3-azido-1-propanol (2) were successfully added to the PHEMA-Alkyne backbone in $\mathrm{DMF}$ with a $\mathrm{CuBr} / \mathrm{PMDETA}$ complex at room temperature by click chemistry, ${ }^{22,23}$ resulting in PEA and PPA, respectively. To ensure $100 \%$ conversion, the twice molar excess amount of 2-azido-1-ethanol to PHEMA-Alkyne backbone was used. The quantitative conversions were observed by ${ }^{1} \mathrm{H}$ NMR spectra, which provided evidence of the successful synthesis of the hydroxyl-functionalized polymers (Figure 2 ). After the click reaction, new peaks ( $m$ and 1 ) representing the proton on the 1,2,3-triazole rings appeared at $7.9 \mathrm{ppm}$ and the proton of terminal $-\mathrm{OH}$ at $5.0 \mathrm{ppm}$ appeared. The integral ratio between peak (m) and (l) was exactly 1, indicating the quantitative click reaction.

In the final polymer modification step, PEA and PPA were

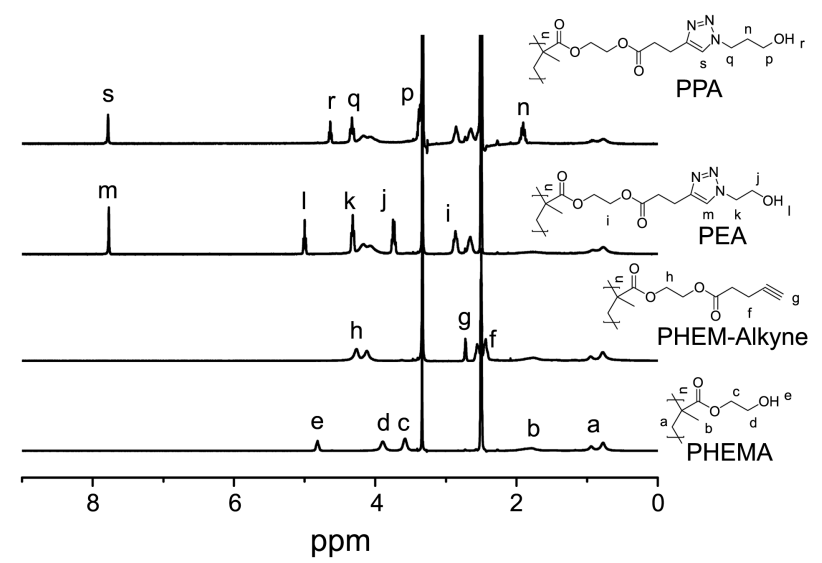

Figure 2. ${ }^{1} \mathrm{H}$ NMR spectra of PHEMA, PHEMA-Alkyne, PEA, and PPA.

partially quaternized with different amounts of methyl iodide to yield various levels of the quaternized polymers, PEA-MI and PPA-MI. Reactions under three different molar feed ratios $(1: 1.5,1: 2.0$, and $1: 2.5)$ of PEA to methyl iodide were conducted in DMF at $45^{\circ} \mathrm{C}$. The degree of quaternization (DQ) for the PEA series was $4 \%, 7 \%$, and $10 \%$, respectively, which was estimated by ${ }^{1} \mathrm{H}$ NMR spectra (Figure 3). As described in our previous results, ${ }^{18}$ the prediction of DQ is difficult due to the quaternization reaction being relatively inefficient. For the quaternization reaction of PEA, a twofold molar excess of methyl iodide over triazole groups in the repeating units of PEA resulted in only a 7\% DQ (PEAMI-7\%). As shown in Figure 3, a new peak (a') representing the proton on the quaternized triazole ring appeared at 8.65 ppm, while the intensity of the proton on the triazole ring without quaternization (a) decreased. As DQ increased, the intensity of peak ( $\left.a^{\prime}\right)$ increased and that of peak (a) decreased. DQ of PEA was calculated from the relative integration areas of peak (a) and (a'). DQ of PPA was $3 \%, 8 \%$, and $11 \%$, which was calculated similarly as described above. Due to volatile nature of methyl iodide (boiling point $=42-43{ }^{\circ} \mathrm{C}$ ) and relatively high reaction temperature $\left(45^{\circ} \mathrm{C}\right)$, loss of methyl iodide is inevitable during the reaction, which led to

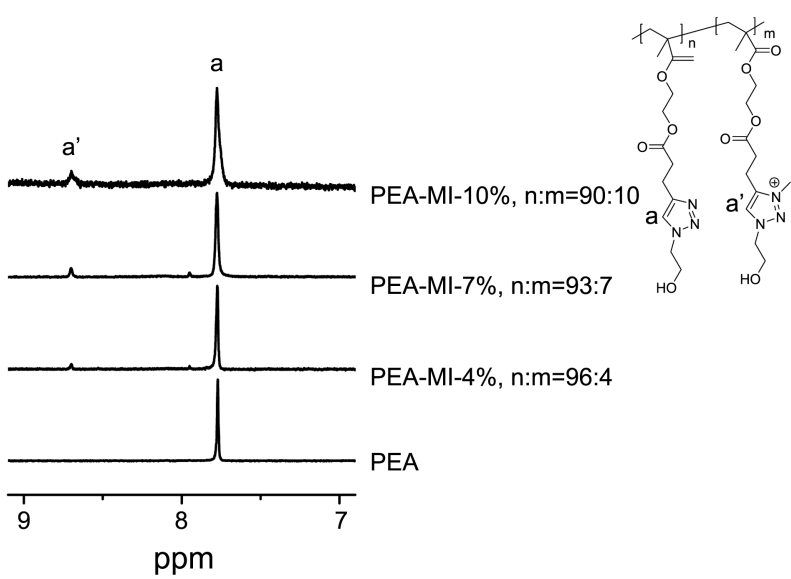

Figure 3. ${ }^{1} \mathrm{H}$ NMR spectra of PEA and its quaternized polymers with different DQ (PEA-MI-4\%, PEA-MI-7\%, and PEA-MI-10\%). 

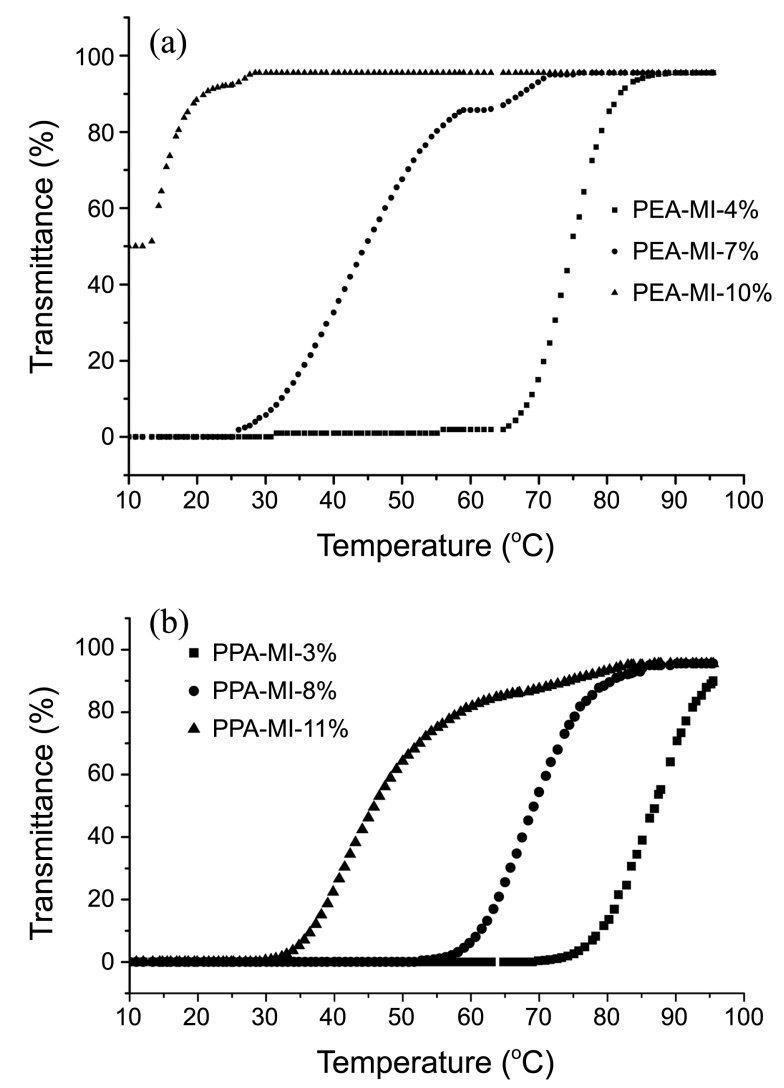

Figure 4. Effect of quaternization on USCT transitions of $1.0 \%$ aqueous solution: (a) PEA series and (b) PPA series measured by percent transmission at $650 \mathrm{~nm}$.

inefficient quaternization.

The UCST transitions of polymers in dilute aqueous solution were monitored by observing changes in the percent transmission at a fixed wavelength $(650 \mathrm{~nm})$ during cooling cycles via UV-Vis spectroscopy. The concentration of all aqueous solutions was fixed at $1.0 \mathrm{wt} \%$ because it is relatively easy to detect cloud points at higher concentrations. The cloud point was defined as the middle point of the transmittance change. Note that quaternized PEA and PPA were not soluble in water even at elevated temperature, meaning that UCST values of these polymers are higher than $100{ }^{\circ} \mathrm{C}$. If these polymers become more hydrophilic by quaternization, one can expect that the UCST would gradually decrease. Indeed, the hydrophilicity of PEA and PPA increased with increasing DQ, which caused the UCST to decrease. It was found that UCST values for the quaternized series of PEA decreased from 75 to $15^{\circ} \mathrm{C}$ as the DQ increased from 4 to $10 \%$ (Figure $4(\mathrm{a})$ ). Similar trends were observed for the quaternized series of PEA (Figure 4(b)). UCST values decreased from 88 to $48^{\circ} \mathrm{C}$ as the DQ increased from 4 to $10 \%$. Since PPA is more hydrophobic than PEA, UCST values of quaternized PEA are higher than those of quaternized PPA when similar DQ was achieved.

\section{Conclusions}

We demonstrated the synthesis of thermoresponsive hydroxyl-derivatized quaternizized polymers with UCST properties via a combination of ATRP and $\mathrm{Cu}(\mathrm{I})$-catalyzed 1,3-dipolar cycloaddition of azide and alkynes, followed by quaternization reaction. The successful synthesis of these polymers was verified by ${ }^{1} \mathrm{H}$ NMR spectroscopy and GPC. It was demonstrated that the polymer UCST could be affected by the existence of ionic groups induced by quaternization of methyl iodide as well as chain-end hydroxyl groups. We also demonstrated that UCST values of hydroxylderivatized quaternized polymers were tuned simply by the $\mathrm{DQ}$ of the triazole rings.

Acknowledgments. This work was supported by University of Ulsan Research Fund of 2013.

\section{References}

1. Bajpai, A. K.; Shukla, S. K.; Bhanu, S.; Kankane, S. Prog. Polym. Sci. 2008, 33(11), 1088-1118.

2. Dimitrov, I.; Trzebicka, B.; Mueller, A. H. E.; Dworak, A.; Tsvetanov, C. B. Prog. Polym. Sci. 2007, 32(11), 1275-1343.

3. Lee, H.-i.; Pietrasik, J.; Sheiko, S. S.; Matyjaszewski, K. Prog. Polym. Sci. 2010, 35(1-2), 24-44.

4. Rapoport, N. Prog. Polym. Sci. 2007, 32(8-9), 962-990.

5. Roy, D.; Cambre, J. N.; Sumerlin, B. S. Prog. Polym. Sci. 2010, 35(1-2), 278-301.

6. Schmaljohann, D. Adv. Drug Delivery Rev. 2006, 58(15), 16551670.

7. Aoshima, S.; Kanaoka, S. Adv. Polym. Sci. 2008, 210, 169-208.

8. Seuring, J.; Agarwal, S. ACS Macro Letters 2013, 2(7), 597-600.

9. Seuring, J.; Bayer, F. M.; Huber, K.; Agarwal, S. Macromolecules 2012, 45(1), 374-384.

10. Seuring, J.; Agarwal, S. Macromol. Rapid. Comm. 2012, 33(22), 1898-920.

11. Costa, R. O. R.; Freitas, R. F. S. Polymer 2002, 43(22), 5879-5885.

12. Hoogenboom, R.; Lambermont-Thijs, H. M. L.; Jochems, M. J. H. C.; Hoeppener, S.; Guerlain, C.; Fustin, C. A.; Gohy, J. F.; Schubert, U. S. Soft Matter 2009, 5(19), 3590-3592.

13. Pagonis, K.; Bokias, G. Polymer 2004, 45(7), 2149-2153.

14. Seuring, J.; Agarwal, S. Macromol. Chem. Phys. 2010, 211(19), 2109-2117.

15. Shimada, N.; Ino, H.; Maie, K.; Nakayama, M.; Kano, A.; Maruyama, A. Biomacromolecules 2011, 12(10), 3418-3422.

16. Aoki, T.; Nakamura, K.; Sanui, K.; Kikuchi, A.; Okano, T.; Sakurai, Y.; Ogata, N. Polym. J. 1999, 31(11), 1185-1188.

17. Glatzel, S.; Laschewsky, A.; Lutz, J. F. Macromolecules 2011 , 44(2), 413-415.

18. Mishra, V.; Jung, S.-H.; Jeong, H. M.; Lee, H.-i. Polym. Chem. 2014, 5(7), 2411-2416.

19. Jung, S.-H.; Song, H.-Y.; Lee, Y.; Jeong, H. M.; Lee, H.-i. Macromolecules 2011, 44(6), 1628-1634.

20. Matyjaszewski, K.; Xia, J. Chem. Rev. 2001, 101(9), 2921-2990.

21. Wang, J.-S.; Matyjaszewski, K. J. Am. Chem. Soc. 1995, 117(20), 5614-15.

22. Lutz, J.-F. Angew. Chem., Int. Ed. 2007, 46(7), 1018-1025.

23. Sumerlin, B. S.; Vogt, A. P. Macromolecules 2010, 43(1), 1-13. 